\title{
Evaluation of the Effects of Topical Vitamin D on Osseointegration of Titanium Implants: An Experimental Study
}

\section{Topikal D Vitamininin Titanyum İmplantların Osseointegrasyonu Üzerine Etkilerinin Değerlendirilmesi: Deneysel Bir Çalışma}

\author{
Alihan BOZOĞLAN ${ }^{1} \mathbb{D}$, Serkan DÜNDAR ${ }^{1}$ (D) \\ ${ }^{1}$ Fırat University, Faculty of Dentistry, Department of Periodontology, Elazığ, TÜRKiYE
}

\section{Abstract}

Background: The aim of this study was to evaluate the effects of topical vitamin D to on osseointegration when applied the surface of titanium implants.

Materials and Methods: Twenty male Spraque-Dawley rats were used in this study in a 4-week experimental period. 4 rats died during the experiments. The rats were divided into 2 groups: a test group and a control group. Sixteen sandblasted and acid-etched implants were integrated surgically in the metaphyseal part of rat femurs after patella dissection. Prior to integration, the implants, which were $3.2 \mathrm{~mm}$ in diameter and $8 \mathrm{~mm}$ in length, were submerged in a $10 \%$ vitamin D solution in the test group. No treatment was applied in the control group. After the 4-week experimental period, the rats were sacrificed, and the implants were removed with surrounding bone tissue. Specimens were fixed for 7 days in a $10 \%$ formaldehyde solution. Bone implant contact (BIC) ratios were determined after using non-decalcified histological methods.

Results: In the experiment, 2 samples were removed because they were not suitable. No statistically significant differences were found for BIC ratios between the test $(n=7)$ and control group $(n=7)$ implants (P>0.05).

Conclusions: It was concluded, within the limitations of this animal study, that topical vitamin D application on implant surfaces does not affect BIC ratios.

Key Words: Osseointegration, Bone-implant contact, Topical vitamin-D, Rat femoral bone

Öz.

Amaç: Bu çalışmanın amacı, titanyum implantların yüzeyine uygulandığında topikal $D$ vitamininin osseointegrasyon üzerindeki etkilerini değerlendirmektir.

Materyal ve Metod: Bu çalışmada 4 haftalık bir deney periyodunda 20 erkek Spraque-Dawley sıçanı kullanıldı. 4 rat deneyler sırasında öldü. Daha sonra ratlar 2 gruba ayrıldı: Test grubu $(n=8)$ ve kontrol grubu $(n=8)$. Patella diseksiyonu sonrası sıçan femurlarının metafiz kısmına 16 tane kumlanmış ve asitle pürüzlendirilmiş implant cerrahi olarak entegre edildi. Entegrasyon öncesinde 3,2 mm çapında ve $8 \mathrm{~mm}$ uzunluğunda olan implantlar, test grubunda \% 10 'luk bir D vitamini çözeltisine daldırıldı. Kontrol grubuna herhangi bir tedavi uygulanmadı. 4 haftalık deney süresinden sonra, sıçanlar öldürüldü ve implantlar çevreleyen kemik dokusuyla birlikte çıkarıldı. Örnekler \% 10 formaldehit solüsyonunda 7 gün fikse edildi. Kemik-implant kaynaşması (BIC) oranları, dekalsifiye edilmemiş histolojik yöntemler kullanılarak belirlendi.

Bulgular: Deneyde 2 örnek uygun olmadığı için çıkartıldı.Test $(n=7)$ ve kontrol grubu $(n=7)$ implantları arasında $B I C$ oranları için istatistiksel olarak önemli farklılıklar tespit edilmedi ( $P>0.05)$.

Sonuç: Bu hayvan çalışmasının sınırları dahilinde, implant yüzeylerine topikal D vitamini uygulamasının BIC oranlarını etkilemediği sonucuna varıldı.

Anahtar kelimeler: Osseointegrasyon, Kemik-implant kaynaşması, Topikal vitamin-D, Sıçan femur kemiği 


\section{Introduction}

Implant-supported prostheses are widely and scientifically accepted as a treatment method for partial and complete edentulism. Success in implant-supported prosthetic treatment depends on the systemic condition of the patient, the quality and quantity of the bone, as well as the design and surface properties of the implant (1-4).

In recent years, research has been conducted to increase the level of osseointegration in dental implants. These studies are carried out to improve the dental implant surface-geometry technology and to improve the quality of the bone in which the implant is placed. Various modification techniques have been shown to increase peri-implant bone quality and quantity, reduce implant costs and treatment times, and improve osseointegration and thus the survival time of the implants (3-8). Biochemical modifications can be accomplished by the topical application of biological mediators to the implant surface and by the application of materials with systemic effects, such as bisphosphonates (9-12).

Vitamin D refers to a group of fatty steroid hormone-derived vitamin types. These hormone structure vitamins are found in various forms, such as ergocalciferol and cholecalciferol. Vitamin D3, also called calcitriol, is formed when the cholesterol in the skin is exposed to UV rays, and it is the most active form of Vitamin $D(13,14)$. Vitamin $D$ has a fundamental function in the biological balance of bone and calcium due to its direct role in calcium absorption in the intestines and kidneys. This molecule also increases the reabsorption of the bone and reduces calcium and phosphate excretion. It has been reported to find vitamin $D$ receptors in osteoblast cells. In addition, vitamin $D$ has a regulatory effect on gene expression. In addition, it is effective on cells that have an important role in bone formation, such as osteocalcin (13-15). In our study, it was aimed to investigate whether topical vitamin $D$ application is effective on titanium implant osseointegration by performing histomorphometric analysis 28 days after titanium implant placement.

\section{Materials and Methods \\ Animals and Experimental Design}

Ethics committee approval of the study was given by Firat University Animal Experiments Local Ethics Committee (Date: 26/10/2016, approval No: 2016/19/191). During the experiment, 20 male Sprague-Dawley rats weight 500550 grams and ages 1-1.6 years were used. 4 rats died during the experiments. During the experiment, rats were kept in cages whose temperature is monitored, on a 12 hour-12 hour light-dark cycle with free access to food and water.

Control Group: Only titanium dental implants were integrated surgically and no treatment was applied during the 4-week experimental period.
Test Group: Before implant placements, dental implants were first submerged into vitamin $D$ solution and then integrated in bone sockets.

\section{Surgical Procedures}

The surgery was performed by applying general anesthesia to the rats. General anesthesia was performed by intramuscular injection of $40 \mathrm{mg} / \mathrm{kg}$ ketamine hydrochloride and $10 \mathrm{mg} / \mathrm{kg}$ xylazine. All sterilization rules were followed during the surgical procedure. Following general anesthesia, the rat skins were washed with povidone-iodine and shaved before surgical application. At the anterolateral part of the knees of the rats, a curved incision was made 10-15 mm in length to access knee joints. Knee joint capsules were then dissected. Each patella was dissected to reveal the intercondylar fossa of the rat femur $(16,17)$. Implant sockets were created with the appropriate drills under the sterile serum physiologic perfusion. After the creation of the bone sockets, the titanium implants were placed into the femoral bone according to the previously described technique (Figure 1). Following surgical implantation of the implants, the joint capsule was repositioned in its original position $(16,17)$. After the surgical procedure, an analgesic and antibiotics were applied intramuscularly for 3 days for all animals. A total of 16 sandblasted and acid-etched implants were integrated into the right femoral bone of the rats. All the surgical applications were done by the same researchers.

\section{Histologic Procedures and Analysis}

The rats were sacrificed 4 weeks after the surgical operations were performed. Then, the implants were removed together with the surrounding bone tissue and samples were obtained. The samples were kept in $10 \%$ formaldehyde solution for 7 days. After fixation, samples were embedded in 2-hydroxymethyl methacrylate resin for cutting un-decalcified bone and titanium with Exakt ${ }^{\circledR}$ microtome (Germany). For histological analysis, implants with surrounding bone tissue were ground with an Exakt ${ }^{\circledR}$ (Germany) grinding machine. To perform light microscopy analysis, $50 \mu \mathrm{m}$ thick sections were obtained, and then these sections were stained with toluidine blue (18). All procedures were carried out in Erciyes University Faculty of Dentistry Research Laboratory. Histological analyzes were performed with a light microscope (Nikon, Japan) located in Firat University Faculty of Medicine, Department of Medical Microbiology. The bone-implant contact (BIC) ratio was determined to determine the total implant surface length in direct contact with the bone.

\section{Statistical Analysis}

For the statistical analysis, SPPS software was used. The data were analyzed, and means and standard deviations were calculated. The Student T-test was used in the data analysis, and a P-value $<0.05$ was considered sufficient to indicate statistical significance $(n=7)$. 

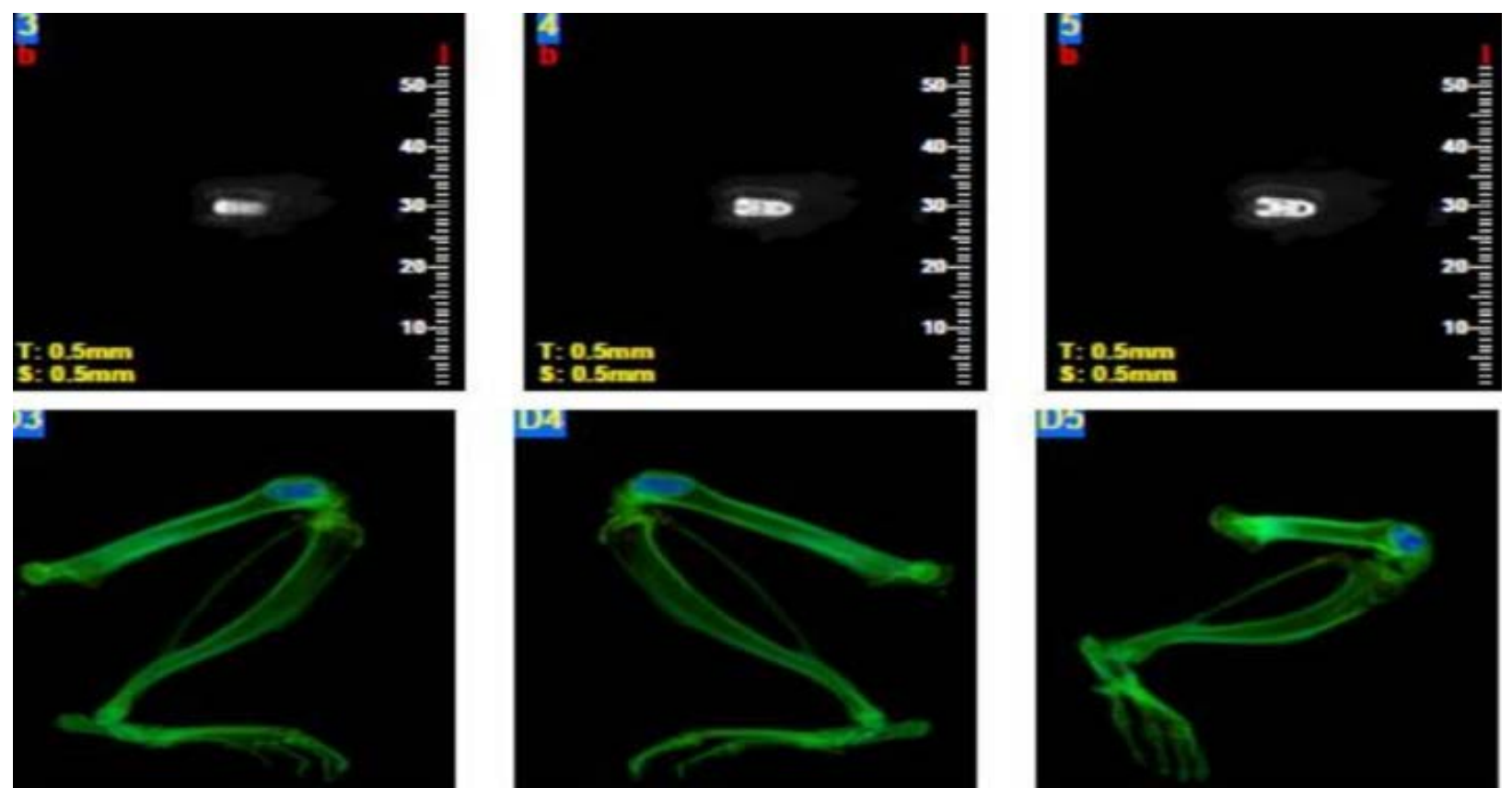

Figure 1. Coronal and sagittal cone beam computerized tomography images of the implant in femur
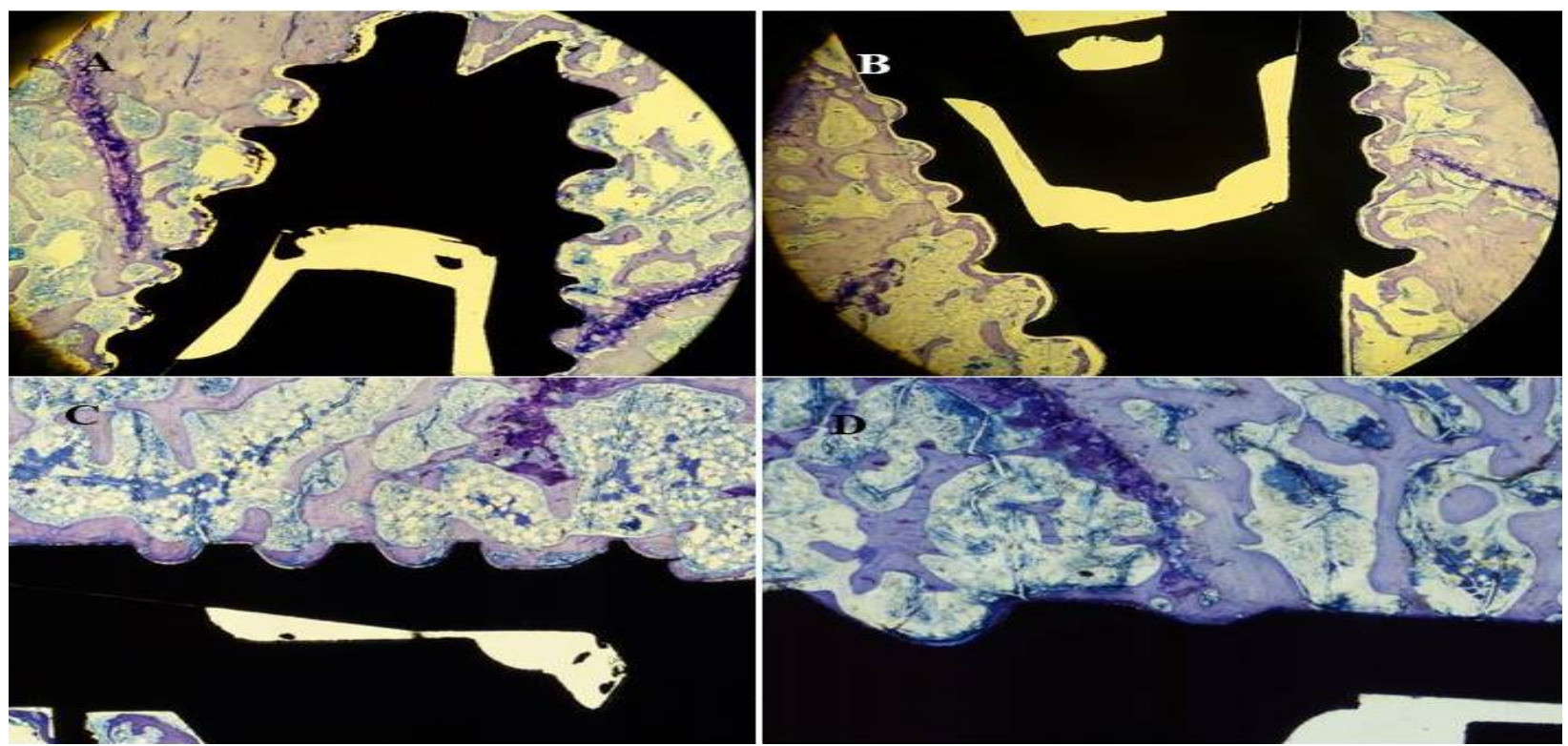

Figure 2. Non-decalcified histologic images of the control (a-2X, b- $4 X)$ and test group implants (c-2X, $d-4 X)(X: 10$ Times Magnification)

\section{Results}

Two specimen was removed from the study group due to improper preparation. The histological BIC data for control and test animals are shown in Table 1 . The mean BIC ratios for control and test animals were $46.14 \%$ and $44.57 \%$, respectively (Figure 2 a,b,c,d). A statistically significant difference was not detected between control and test animals for $\mathrm{BIC}$ ratios $(\mathrm{P}>0.05)$.

Table 1. Mean bone implant contact (BIC) ratio of the groups. P: 0.508 (Student T test)

\begin{tabular}{|l|c|c|}
\hline \multicolumn{1}{|c|}{ Groups } & BIC (Mean \pm std) $\mathbf{( \% )}$ & P \\
\hline Controls $(\mathbf{n}=\mathbf{7})$ & $46.14 \pm 4.63$ & \multirow{2}{*}{$\mathrm{P}>0.05$} \\
\hline Tests $(\mathbf{n}=\mathbf{7})$ & $45.57 \pm 2.82$ & \\
\hline
\end{tabular}

\section{Discussion}

The effects of various factors such as bone morphogenetic proteins, growth hormone, melatonin, and hydroxyapatite-calcium deposits have been investigated in order to increase the regeneration capacity in peri-implant bone tissue $(3,9-12,19-23)$. It has been suggested that vitamin D stimulates osteoblast proliferation and differentiation, thereby increasing bone formation. However, it has been reported that topical vitamin D application on the osseointegration level of dental implants should be discussed $(24,25)$. In this study, no statistically significant difference was observed in osseointegration between controls and 
test animals with topical vitamin $D$ application on implants. Naito et al. (19), in a 6-week experimental study utilizing rabbit tibias, examined the effects of topical application of vitamin D on BIC and new bone formation. In their study, Naito et al. (19) compared 3 doses of topical vitamin D with untreated controls, using machined surface implants. In a study, no statistically significant difference was found between test and control groups after 6 weeks of experimentation. It has been reported that this is due to either the inadequate maintenance of the vitamin $D$ loss that occurs during the vitamin D coating process. Naito et al. (19) have been reported that the use of implants with a rough surface may increase osseointegration. In our study, we used 1-2 Ra sandblasted, acid-etched implants, and our results did not support this hypothesis. However, Cho et al. (24) integrated vitamin D coated anodized surface implants in rabbit tibia and determined the osseointegration ratio histologically after 4 and 12 weeks. They reported that vitamin D coating statistically improved osseointegration when compared with the controls, after both 4 and 12 weeks. In another study, Fügl et al. (25) reported that topical vitamin $D$ did not effects new bone formation. They used 60 rats divided into 3 experimental groups: a vitamin D deficiency, and ungrafted group, a vitamin deficiency and local calcitriol application group, and a control group. Fügl et al. (25) created $2 \mathrm{~mm}$ circumferential diameter defects in rat mandibles and sacrificed animals after 1 and 3 weeks. After 1 week, bone formation was not obtained, but after 3 weeks, new bone formation was detected and was statistically significantly higher in the vitamin D deficiency and ungrafted groups when compared to controls and the other group (the group with vitamin D deficiency and topical calcitriol application). Additionally, SalomoColl et al. (26) integrated immediate implant in dog mandible after the extraction of mandibular premolar distal root and evaluated the BIC and bone formation after a 12week experimental period. They reported that no statistically significant differences were detected for BIC, new bone formation, and interthread bone between the two groups. Additionally, they reported that topical vitamin D application could reduce crestal bone loss when compared with controls. Salomo-Coll et al. (26) suggested that this result stemmed from inadequate methods for vitamin $D$ application since animals were healthy and vitamin D has more potential effects on bone metabolism in populations with low vitamin D levels. Our results appear to confirm Salomo-Coll et al.'s results with no statistically significant differences detected between test and control animals (26). Additionally, in their study, the authors used roughsurfaced implants. Their results, like ours, do not support Naito et al.'s hypothesis that topical vitamin D on roughened surfaces may have positive effects on bone metabolism (19).

\section{Conclusion}

In our study, we concluded that topical vitamin D application did not improve osseointegration of sandblasted and acid-etched implants in rat femur after a 4-week experimental period. The potential effects of topical and systemic vitamin $D$ application on peri-implant bone tissues are unclear. Further studies are needed to clarify the association of topical vitamin D application and osseointegration of implants.

\section{Acknowledgement}

All of the experimental and surgical protocols in our study were carried out in the Experimental Research Center of Firat University. Ethics committee approval of the study was given by Furat University Animal Experiments Local Ethics Committee (Date: 26/10/2016, approval No: 2016/19/191).

The animals used in the study were provided by Firat University Experimental Research Center. The authors wish to thanks (Bioinfinity Dental Implant System, Avrupa Dental Implant Corporation, Istanbul, Turkiye) for manufacturing and providing the titanium implants.

The information presented in this study was presented as an oral presentation at the Turkish Dental Association 24th International Congress of Dentistry between 27-30 September 2018.

Ethical Approval: Ethics committee approval of the study was given by Firat University Animal Experiments Local Ethics Committee (Date: 26/10/2016, approval No: 2016/19/191).

\section{Author Contributions:}

Concept: A.B., S.D.

Literature Review: A.B., S.D.

Design : A.B., S.D.

Data acquisition: A.B., S.D.

Analysis and interpretation: A.B., S.D.

Writing manuscript: A.B., S.D.

Critical revision of manuscript: A.B., S.D.

Conflict of Interest: The authors decelerate there is no conflict of interest.

Financial Disclosure: The authors do not have any financial interests, either directly or indirectly, in the products or information listed in the paper.

\section{References}

1. Lantto A, Lundqvist R, Wårdh I. Oral Status and Prosthetic Treatment Needs in Functionally Impaired and Elderly Individuals. Int J Prosthodont. 2017 Nov 22. doi: 10.11607/ijp.5491. [Epub ahead of print]

2. Ayub KV, Ayub EA, Lins do Valle A, Bonfante G, Pegoraro T, Fernando L. Seven-Year Follow-up of Full-Arch Prostheses Supported by Four Implants: A Prospective Study. Int J Oral Maxillofac Implants. 2017; 32(6):1351-58.

3. Dundar S, Yaman F, Saybak A, et.al. Evaluation of Effects of Topical Melatonin Application on Osseointegration of Dental Implant: An Experimental Study. J Oral Implantol 2016; 42(5): 386-89.

4. Le Guehennec L, Goyenvalle E, Lopez-Heredia M-A, et.al. 
Histomorphometric analysis of the osseointegration of four different implant surfaces in the femoral epiphyses of rabbits. Clin Oral Impl Res 2008; 19: 1103-10.

5. Rupp F, Liang L, Geis-Gerstorfer J, Scheideler L, Hüttig F. Surface characteristics of dental implants: A review. Dent Mater. 2018; 34(1): 40-57.

6. Le Guehennec L, Soueidan A, Layrolle P, Amouriq Y. Surface treatments of titanium dental implants for rapid osseointegration. Dental Materials 2007; 23: 844-54.

7. Buser D, Schenk RK, Steinemann S, et.al. Influence of surface characteristics on bone integration of titanium implants. A histomorphometric study in miniature pigs. J Biomed Mater Res 1991; 25:889-902.

8. Albrektsson $T$, Wennerberg A. Oral implant surfaces: Part 1-review focusing on topographic and chemical properties of different surfaces and in vivo responses to them. Int J Prosthodont 2004; 17:536-43.

9. Dundar S, Yaman F, Gecor O, et. al. Effects of Local and Systemic Zoledronic Acid Application on Titanium Implant Osseointegration: An Experimental Study Conducted on Two Surface Types. J Craniofac Surg 2017; 28(4): 935-38.

10. Abduljabbar T, Kellesarian SV, Vohra F, Akram Z, Kotsakis GA, Yunker M, et. al. Effect of Growth Hormone Supplementation on Osseointegration: A Systematic Review and Meta-analyses. Implant Dent. 2017; 26(4): 613-20.

11. Wang $\mathrm{T}$, Muhetaer $\mathrm{H}$, Li J. Experimental study of transforming growth factor- $\beta 3$ combined with dental pulp stem cells in promoting the implant's osseointegration. Zhonghua Kou Qiang Yi Xue Za Zhi. 2017; 52(6): 367-73.

12. Apostu $D$, Lucaciu $O$, Lucaciu GD, Crisan B, Crisan L, Baciut $M$, et. al. Systemic drugs that influence titanium implant osseointegration. Drug Metab Rev. 2017; 49(1): 92-104.

13. Salomó-Coll $O$, Maté-Sánchez de Val JE, Ramírez-Fernandez MP, Hernández-Alfaro F, Gargallo-Albiol J, Calvo-Guirado $\mathrm{JL}$. Topical applications of vitamin D on implant surface for bone-to-implant contact enhance: a pilot study in dogs part II. Clin Oral Implants Res. 2016; 27(7): 896-903.

14. Javed F, Malmstrom H, Kellesarian SV, Al-Kheraif AA, Vohra $F$, Romanos GE. Efficacy of Vitamin D3 Supplementation on Osseointegration of Implants. Implant Dent. 2016; 25(2): 281-7.

15. Liu W, Zhang S, Zhao D, Zou H, Sun N, Liang X, et. al. Vitamin $D$ supplementation enhances the fixation of titanium implants in chronic kidney disease mice. PLoS One. 2014; 9(4): e95689.

16. Urbanski W, Marycz K, Krzak J, Pezowicz C, Dragan SF. Cytokine induction of sol-gel-derived $\mathrm{TiO} 2$ and $\mathrm{SiO} 2$ coatings on metallic substrates after implantation to rat femur. Int J Nanomedicine 2017;12:1639-45.

17. Ying G, Bo L, Yanjun J, Lina W, Binquan W. Effect of a local, one time, low-dose injection of zoledronic acid on titanium implant osseointegration in ovariectomized rats. Arch Med Sci 2016;12(5): 941-9.

18. Donath $\mathrm{K}$, Breuner $\mathrm{G}$. A method for the study of undecalcified bones and teeth with attached soft tissues. The SageSchliff (sawing and grinding) technique. J Oral Pathol 1982; 11: 318-26.

19. Naito $Y$, Jimbo $R$, Bryington $M S$, Vandeweghe $S$, Chrcanovic

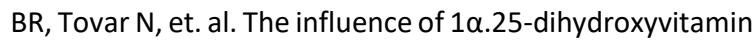
d3 coating on implant osseointegration in the rabbit tibia. J Oral Maxillofac Res. 2014; 5(3): e3.
20. Alhilou A, Do T, Mizban L, Clarkson BH, Wood DJ, Katsikogianni MG. Physicochemical and Antibacterial Characterization of a Novel Fluorapatite Coating. ACS Omega. 2016; 1(2): 264-76.

21. Mihailescu N, Stan GE, Duta L, Chifiriuc MC, Bleotu C, Sopronyi $\mathrm{M}$, et. al. Structural, compositional, mechanical characterization and biological assessment of bovine-derived hydroxyapatite coatings reinforced with MgF2 or $\mathrm{MgO}$ for implants functionalization. Mater Sci Eng C Mater Biol Appl. 2016; 59: 863-74.

22. Lavos-Valereto IC, Wolynec S, Deboni MC, König B Jr. In vitro and in vivo biocompatibility testing of Ti-6Al-7Nb alloy with and without plasma-sprayed hydroxyapatite coating. J Biomed Mater Res. 2001; 58(6): 727-33.

23. Eliaz N, Metoki N. Calcium Phosphate Bioceramics: A Review of Their History, Structure, Properties, Coating Technologies and Biomedical Applications. Materials (Basel). 2017;10(4): e334.

24. Cho YJ, Heo SJ, Koak JY, Kim SK, Lee SJ, Lee JH. Promotion of osseointegration of anodized titanium implants with a 1 $\alpha, 25$-dihydroxyvitamin D3 submicron particle coating. Int J Oral Maxillofac Implants. 2011; 26(6): 1225-32.

25. Fügl A, Gruber R, Agis $H$, Lzicar $H$, Keibl C, Schwarze UY, et. al. Alveolar bone regeneration in response to local application of calcitriol in vitamin D deficient rats. J Clin Periodontol. 2015; 42(1): 96-103.

26. Salomó-Coll O, Maté-Sánchez de Val JE, Ramírez-Fernandez MP, Hernández-Alfaro F, Gargallo-Albiol J, Calvo-Guirado JL. Topical applications of vitamin D on implant surface for bone-to-implant contact enhance: a pilot study in dogs part II. Clin Oral Implants Res. 2016; 27(7): 896-903. 